\title{
Gender difference analysis of Xp11.2 translocation renal cell carcinomas's attack rate: a meta-analysis and systematic review
}

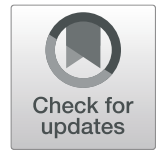

Wenyuan Zhuang ${ }^{1}$, Ning Liu', Hongqian Guo', Chunni Zhang ${ }^{2 *}$ and Weidong Gan ${ }^{1 *}$

\begin{abstract}
Background: Xp11.2 translocation renal cell carcinoma (tRCC) is recently recognized. As Xp11.2 tRCC involved gene translocation and fusion in $X$ chromosome and the number of $X$ chromosomes in female is twice of male, we wondered whether the gender difference of attack rate is consistent with the proportion of the $X$ chromosome. Methods: In the present paper, meta-analysis was performed to find out the difference of morbidity between male and female.

Results: Nine studies with 209 cases calculated. Odds ratios (ORs) and ORs with 95\% confidence intervals (Cls) were calculated for attack rate of Xp11.2 RCC with different gender. The result showed that the attack rate of female was higher than that of male with pooled OR of $2.84(95 \% \mathrm{Cl}=1.48-5.45)$, while the rate rises even further in adult $(\mathrm{OR}=3.37,95 \% \mathrm{Cl}=2.19-5.18)$. In other types of common kidney cancer, the OR value is less than 1 , which means that the incidence of female is lower than that of male.

Conclusions: The result showed that the incidence rate of female patients is much higher than that of male patients with Xp11.2 tRCC, it was reasonable to indicate that this particular incidence rate is related to the $X$ chromosome.
\end{abstract}

Keywords: Xp11.2, tRCC, TFE3, Gender, X chromosome

\section{Background}

Xp11.2 translocation renal cell carcinoma (tRCC) was delineated as a distinct entity in the 2004 World Health Organization (WHO) renal tumor classification [1]. Recently, the published WHO classification of tumors classified the Xp11.2 tRCC as one of MiT (microphthalmia transcription factor) family tRCC [2]. A total of 5 Xp11.2 tRCCs have been identified in RCC tumors,

\footnotetext{
*Correspondence: zchunni27@hotmail.com; gwd@nju.edu.cn; dr.gwd@yeah.net

2Department of Clinical Laboratory, Jinling Hospital, State Key Laboratory of Analytical Chemistry for Life Science, Jiangsu Engineering Research Center for MicroRNA Biology and Biotechnology, Nanjing University School of Medicine, Nanjing University, Nanjing, China

'Department of Urology, Nanjing Drum Tower Hospital, Medical School of Nanjing University, Institute of Urology, Nanjing University, 321 Zhongshan Road, Nanjing 210008, China
}

PRCC-TFE3, ASPSCR1-TFE3, SFPQ-TFE3, NONO-TFE3, and CLTC-TFE3, all of which result in TFE3 (transcription factor binding to IGHM enhancer 3) gene fusions [3]. TFE3 gene is located on the short arm of the X chromosome (Xp11.2). The functional domain of the TFE3 gene fused with the promoter of other genes, housekeeping gene usually, resulting to the TFE3 protein is constitutively overexpressed in Xp11.2 tRCC which can be specifically identified by IHC (immunohistochemistry) $[4,5]$.

$\mathrm{Xp11.2}$ tRCC is predominantly reported in children and young adults less than 45 years of age with a onethird incidence in juveniles [6]. Adult patients are rare reported with an incident rate of $1 \%$. Xp11.2 tRCC shared similar feature to conventional clear cell and papillary renal carcinomas in histology, which creates diagnostic difficulties, and the fact is one possibility to

C C The Author(s). 2020 Open Access This article is licensed under a Creative Commons Attribution 4.0 International License, which permits use, sharing, adaptation, distribution and reproduction in any medium or format, as long as you give appropriate credit to the original author(s) and the source, provide a link to the Creative Commons licence, and indicate if changes were made. The images or other third party material in this article are included in the article's Creative Commons licence, unless indicated otherwise in a credit line to the material. If material is not included in the article's Creative Commons licence and your intended use is not permitted by statutory regulation or exceeds the permitted use, you will need to obtain permission directly from the copyright holder. To view a copy of this licence, visit http://creativecommons.org/licenses/by/4.0/ The Creative Commons Public Domain Dedication waiver (http://creativecommons.org/publicdomain/zero/1.0/) applies to the data made available in this article, unless otherwise stated in a credit line to the data. 
explain the problem of its frequency $[7,8]$. However, Xp11.2 tRCC showed more aggressive behavior, with metastasis common at presentation, and poorer prognosis than other subtypes of RCC. In addition, previous studies revealed that Xp11.2 tRCC was inherently more aggressive in adults than that in children [9]. Complete surgical removal of the tumor mass including the kidney may be the preferred therapy in patients with lower stage tumors. Today, the clinical characteristic and epidemiology of Xp11.2 tRCC are not very clear for the rarity of Xp11.2 tRCC. Controversy about the gender difference of morbidity remained unclear. Several published studies showed the female predominance in incidence of Xp11.2 tRCC while a few studies reported it is seen more often in males than in females [1].
As Xp11.2 tRCC involved gene translocation and fusion in $\mathrm{X}$ chromosome and the number of $\mathrm{X}$ chromosomes in female is twice of male, we are interested in the relation of female predominance in attack rate of Xp11.2 tRCC and the sex chromosome. We wondered whether the gender difference of attack rate is consistent with the proportion of the $\mathrm{X}$ chromosome. Gender factor was significantly associated with the frequency of many diseases and Xp11.2 tRCC might be one of them $[10,11]$. However, up to date, studies on large sample for analysis of the clinical characteristic and epidemiology of Xp11.2 tRCC were still lack. Therefore, we analyzed the difference of morbidity between male and female in this systematic review by using meta-analysis and investigated the potential role of $\mathrm{X}$ chromosome on

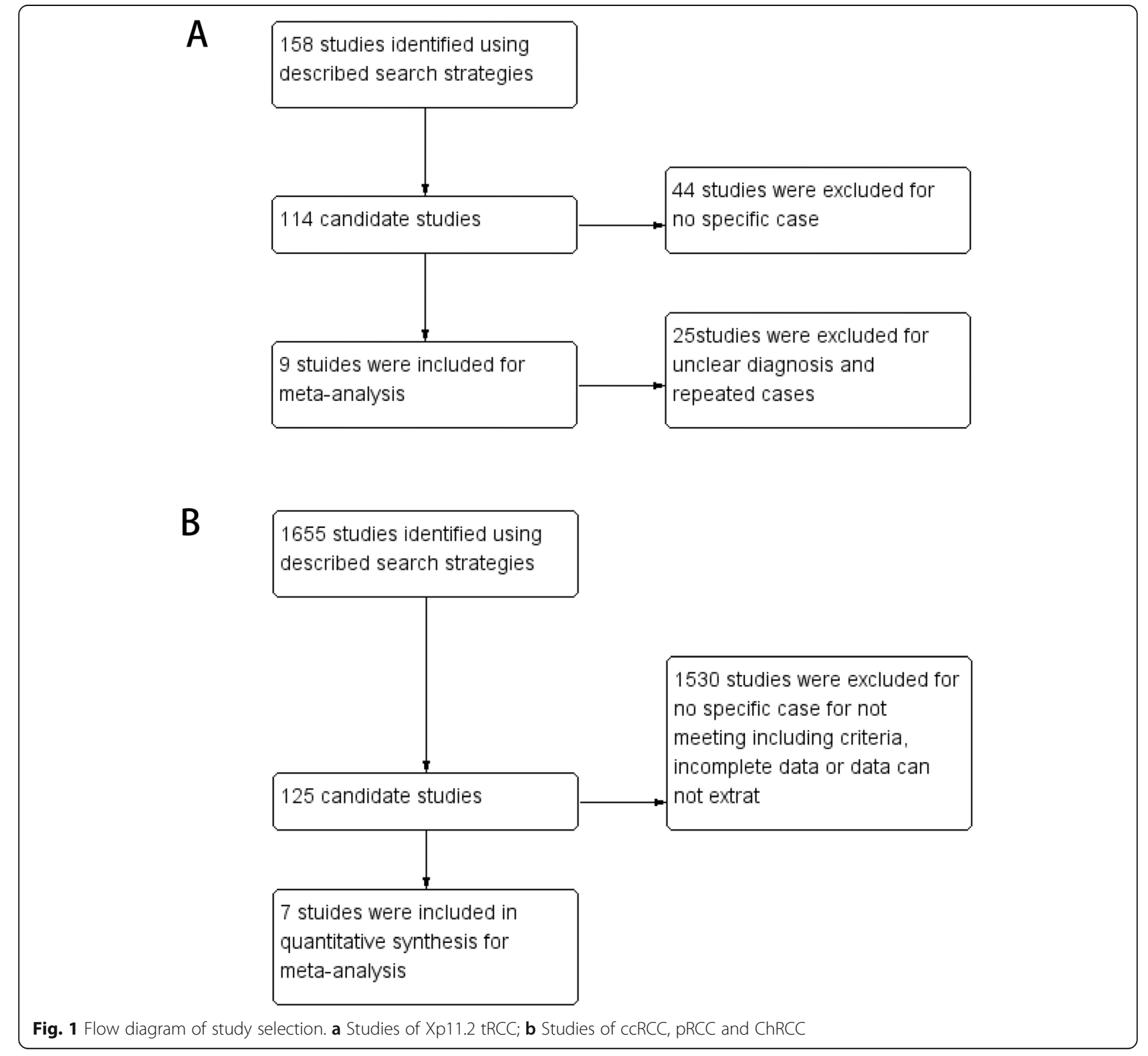




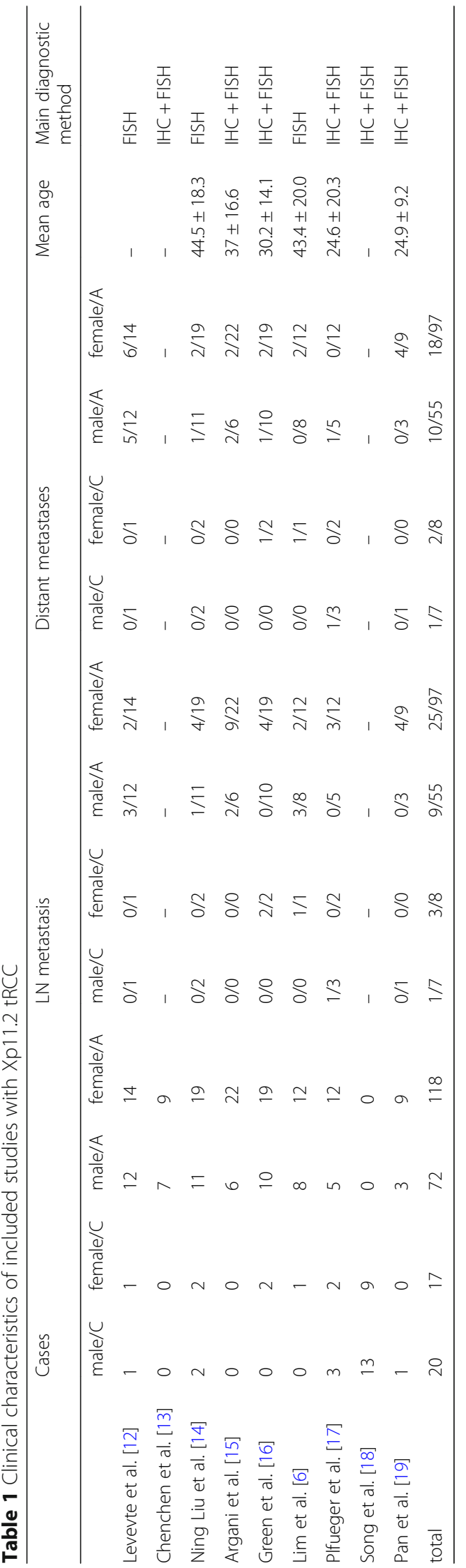


Xp11.2 tRCC. For comparison, we also analyzed clear cell carcinoma (ccRCC), papillary cell carcinoma (pRCC), and chromophobe cell carcinoma (ChRCC).

\section{Methods}

\section{Literature search and study selection}

A computer-aided literature search was performed with usage of the Cochrane, DARE, MEDLINE, EMBASE, and Science Citation Index. The literature published between July 2004 and May 2019 was searched. An initial search strategy used recognized search terms "TFE3" and "Xp11.2 renal cell carcinoma". Primary studies that meet following criteria were included: (1) All studies that reported cases with definite gender; (2) All cases were confirmed by specific biological technology, such as IHC assay for TFE3, FISH, RT-PCR, and/or other molecular biology methods. (3) The report contained enough cases $(\geq 10)$. Reviews and mechanism researches were excluded. Studies that performed in the lab with animal or cell models were also excluded. We also collected common types of renal cell carcinoma for comparison, searches included the terms "clear cell renal cell carcinoma" and "papillary renal cell carcinoma" and "chromophobe renal carcinoma". The citations listed in the retrieved articles were reviewed to identify other potentially relevant studies. Primary studies that meet following criteria were included: (1) The patient was diagnosed as renal cell carcinoma. (2) Patients have clear data of treatment and follow-up. (3) There is sufficient data for analysis. All studies were evaluated carefully to eliminate duplicate patient populations. Figure 1 shows a flow diagram.

\section{Data synthesis and analysis}

We paid our attention to the difference of morbidity between male and female and all primary studies with gender data were analyzed. The statistical software Review Manager (Version 5.3 for Windows) was applied to carry out all the analysis. Dichotomous data which incidence regarded were expressed as odds ratios (ORs) and ORs with 95\% confidence intervals (CIs) were used in the Mantel-Haenszel fixed-effect model when no statistically significant heterogeneity was detected. On the contrary, Mantel-Haenszel random-effect model would be chosen when heterogeneity was significant. Heterogeneity analysis was performed using the Cochran $Q$-test and $\mathrm{I}^{2}$ index, the existence of heterogeneity statistically was considered when the $p$ value was less than 0.1. On the other

Table 2 Clinical characteristics of included studies with $c C R C C$, pRCC and ChRCC

\begin{tabular}{|c|c|c|c|c|c|}
\hline \multicolumn{6}{|l|}{ PRCC } \\
\hline & male & female & LN metastasis & Distant metastases & $\overline{\text { Mean age }}$ \\
\hline Beck et al. [20] & 117 & 40 & - & $9 / 157$ & $62.2 \pm 12$ \\
\hline Toloken et al. [21] & 236 & 74 & $7 / 310$ & unknown & 64 \\
\hline Keengan et al. [22] & 1740 & 538 & $67 / 2278$ & $98 / 2278$ & - \\
\hline Sterffens et al. [23] & 436 & 129 & $50 / 565$ & $54 / 565$ & $62.1 \pm 11.6$ \\
\hline Lee et al. [24] & 142 & 50 & unknown & unknown & $56.4 \pm 13.5$ \\
\hline Simone et al. [25] & 40 & 15 & $13 / 55$ & $5 / 55$ & $59.1 \pm 14.8$ \\
\hline Wagener et al. [26] & 1469 & 474 & 143/1943 & $151 / 1943$ & - \\
\hline \multicolumn{6}{|l|}{ CCRCC } \\
\hline & male & female & LN metastasis & Distant metastases & Mean age \\
\hline Beck et al & 487 & 307 & - & $95 / 794$ & $61.5 \pm 12$ \\
\hline Toloken et al & 836 & 497 & 23 & - & 62 \\
\hline Keengan et al & 8501 & 5340 & $172 / 13841$ & $1219 / 12841$ & - \\
\hline Sterffens et al & 2772 & 1604 & $319 / 4376$ & $618 / 4376$ & $62.4 \pm 11.2$ \\
\hline Lee et al & 1785 & 703 & - & - & $56.1 \pm 12.4$ \\
\hline Simone et al & 599 & 321 & 29/920 & $68 / 920$ & $59.8 \pm 12.6$ \\
\hline Wagener et al & 3357 & 2243 & $210 / 5600$ & $540 / 5600$ & - \\
\hline \multicolumn{6}{|l|}{ Chromophobe } \\
\hline & male & female & LN metastasis & Distant metastases & Mean age \\
\hline Beck et al & 59 & 47 & - & $6 / 106$ & $57.5 \pm 12$ \\
\hline Toloken et al & 120 & 100 & 4 & - & 59 \\
\hline Keengan et al & 568 & 381 & $11 / 949$ & $36 / 949$ & - \\
\hline
\end{tabular}


hand, evaluation of publication bias was performed for each of the pooled study groups using a funnel plot.

\section{Results}

\section{Literature and study characteristics}

All published cases of Xp11.2 tRCC were enrolled except a few of cases could not meet the inclusion criteria. Nine studies with 209 cases were collected. It was also checked that all cases were unique, no repeated cases were included. For common types of kidney cancer, 7 studies were included in quantitative synthesis for meta-analysis, as shown in Table 1 and Table 2. Publication bias is described as visual assessment of a funnel plot in Fig. 2 and there was no evidence for significant publication bias.

\section{Results of the search \\ All collected studies}

Totally, there were 131 females and 78 males while all the cases according our inclusion criteria were enrolled in. Previous literature has reported significant gender differences in Xp11.2 tRCC between adults and children, so patients of Xp11.2 tRCC was divided into children ( $\leq 14$ years) and adults ( $>14$ years) for further analysis. The three most common types of renal cell carcinoma, clear cell carcinoma, papillary cell carcinoma, and chromophobe cell carcinoma, were used for comparative analysis.

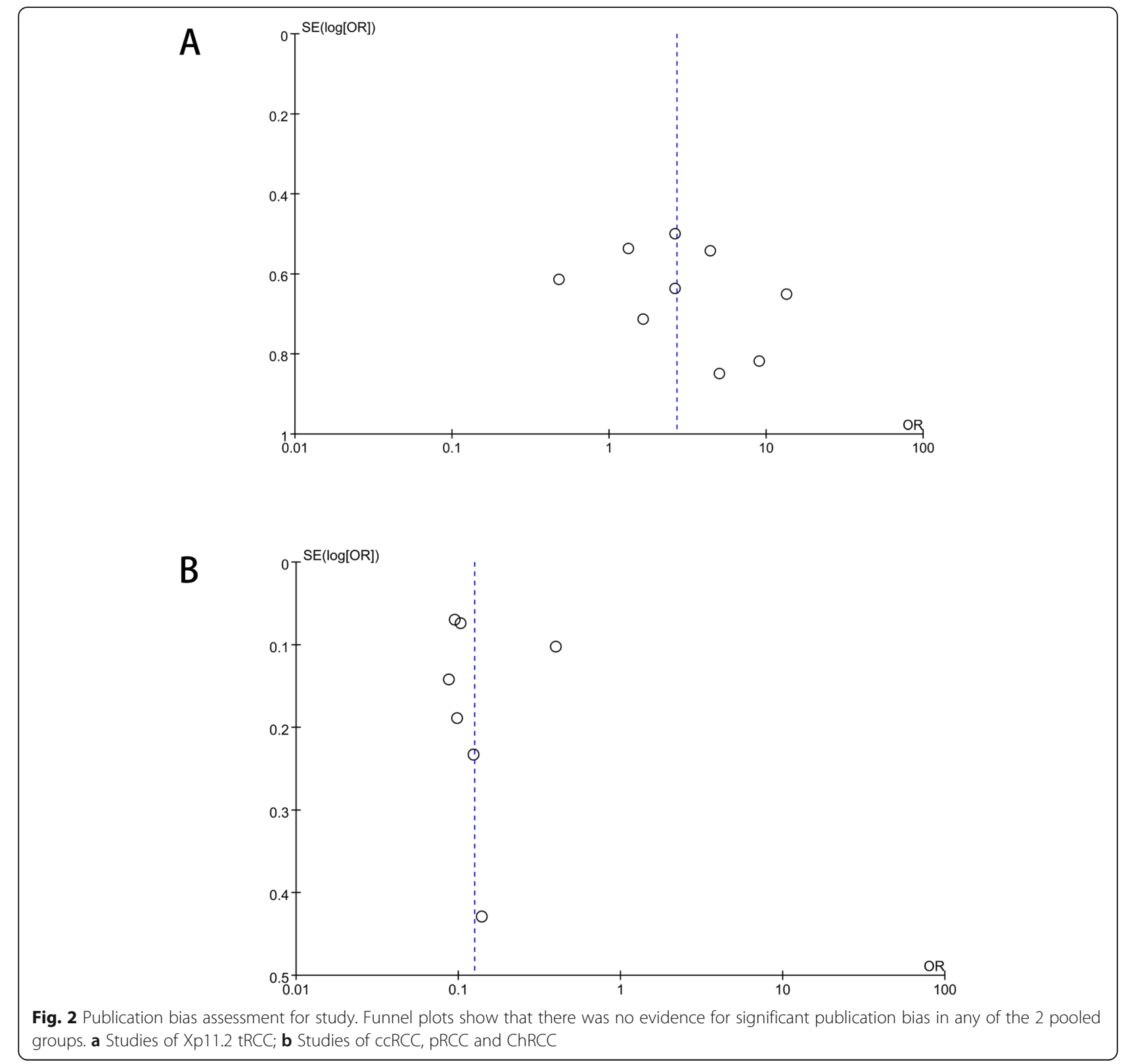




\section{Gender-related incidence of all included studies of Xp11.2 tRCC}

A total of 209 cases with 131 women and 78 men were included. Tests for heterogeneity showed that $P=0.002$ and $\mathrm{I}^{2}=60 \%$. We applied random- effect model while $\mathrm{I}^{2}$ value $>50 \%$. Pooled OR was $2.84(95 \% \mathrm{CI}=1.48-5.45)$ (Fig. 3a).

\section{Gender-related incidence of included adult studies of Xp11.2 tRCC}

A total of 178 cases of Xp11.2 with 116 women and 62 men were included. $\left(I^{2} \quad\right.$ statistic $=31 \%$, $P<0.00001)$, so that Mantel-Haenszel fixed-effect model was still applied. Pooled OR was 3.37 (95\% CI $=2.19-45.18$ ) (Fig. 3b).

\section{Gender-related incidence of included children studies of Xp11.2 tRCC}

For this group, there was no evidence for heterogeneity about incidence of different gender $\left(I^{2}\right.$ statistic $=0 \%, P=$ 0.52). Results of meta-analysis demonstrated that The incidence is similar between male and female with pooled OR of $0.76(95 \% \mathrm{CI}=0.32-1.77)$ (Fig. 3c).

\section{Gender-related incidence of PRCC, CCRCC and ChRCC}

Seven studies were included in quantitative synthesis for meta-analysis. For pRCC, a total of 5500 cases with 1320 women and 4180 men were included. The pooled OR was $0.10(95 \% \mathrm{CI}=0.09-0.11)$ (Fig. 4b). For ccRCC, we got similar results. The pooled OR was 0.32 (95\% CI $=0.26-0.41)$ (Fig. 4a). Results of ChRCC showed that the OR of ChRCC was $0.47(95 \% \mathrm{CI}=$ 0.39-0.56) (Fig. 4c).
Gender-related distant and lymphatic metastases of Xp11.2 tRCC

A total of 209 cases with 131 women and 78 men were included. Tests for heterogeneity showed that no evidence of heterogeneity in the incidence of distant metastasis $\left(I^{2}\right.$ statistic $\left.=32 \%, P=0.86\right)$ and lymphatic metastasis $\left(I^{2}\right.$ statistic $\left.=0 \%, P=0.35\right)$ was observed in two pool. The results showed that the rates of lymphatic metastasis $(\mathrm{OR}=1.47,95 \% \mathrm{CI}=0.66-3.24)$ (Fig. 5a) and distant metastasis $(\mathrm{OR}=1.09,95 \% \mathrm{CI}=0.44-1.72)$ (Fig. $5 \mathrm{~b}$ ) were comparable between male and female patients.

\section{Discussion}

Xp11.2 tRCCs, as rare tumors, seen more often in children and young adults, account for less than $5 \%$ of all sporadic kidney cancers. It is reported that the prognosis for Xp11 tRCC is similar to that for clear cell RCC in adult while children with Xp11 tRCC may have a more favorable outcome $[12,13,27,28]$. Since the first described fusion of TFE3 on the short arm of the $\mathrm{X}$ chromosome to chromosome 1q21.2 [PRCC-TFE3 $\mathrm{t}(\mathrm{X}$; 1)(p11.2;q21)], several other TFE3 translocation partners have been identified, including at least five different fusion partners of the Xp11.2 chromosome: ASPL-TFE3, PRCC-TFE3, PSF-TFE3, CLTC-TFE3, and NoNo -TFE3 [14-16, 29-31]. Other novel fusion partners in single case, PARP14, KHSRP, and DVL2, were recently described. Yet despite nearly two decades since the discovery of Xp11.2 tRCCs, the morphology, biological behavior, and molecular biology underlying these cancers remains largely uncharacterized and effective targeted therapies are yet to be identified.

The translocations on chromosome Xp11.2 result in fusions between TFE3 and its respective fusion partners varies and can produce fusions containing differing number of exons in the case of TFE3 and its gene

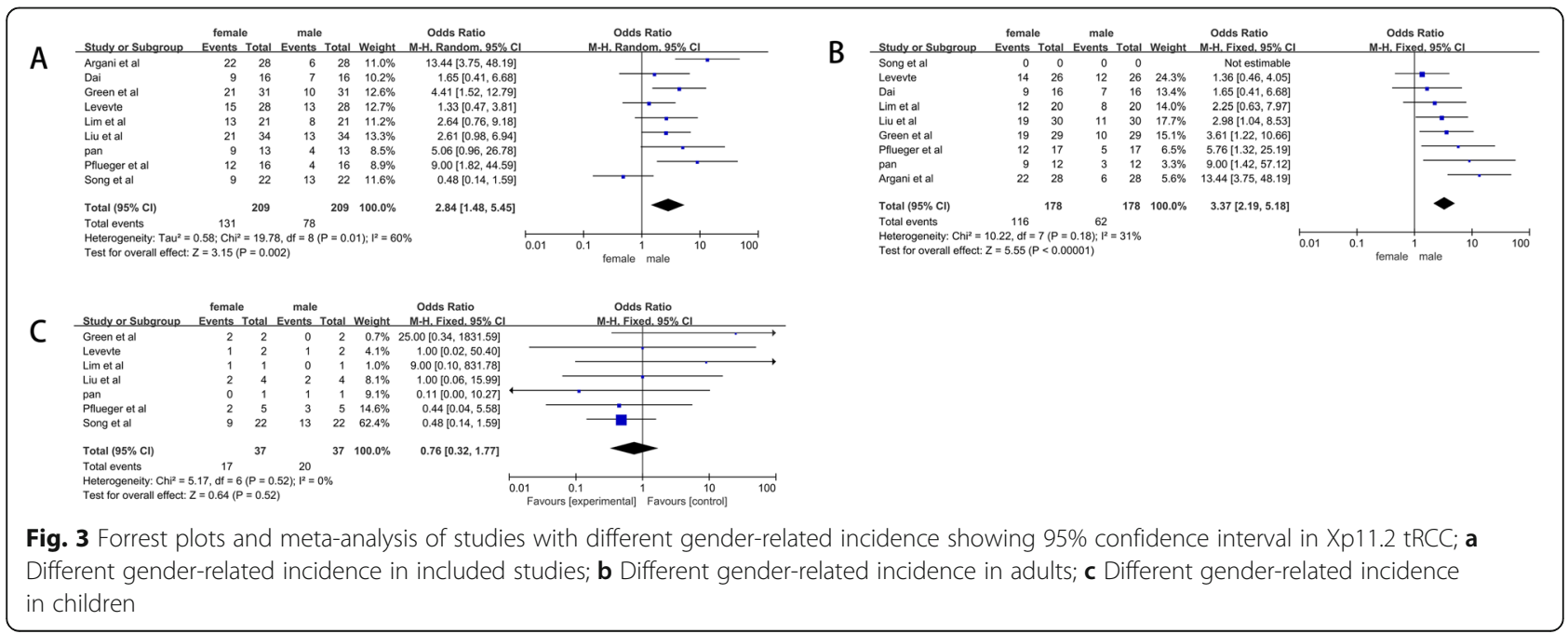



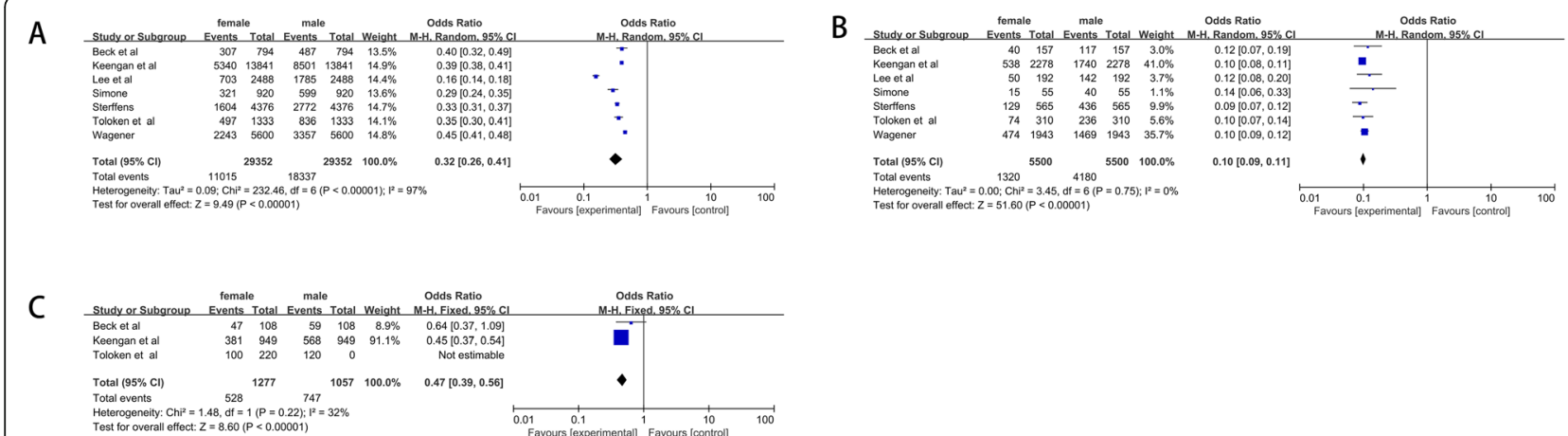

Fig. 4 Forrest plots and meta-analysis of studies with different gender-related incidence showing $95 \%$ confidence interval in $c C R C C$, pRCC and

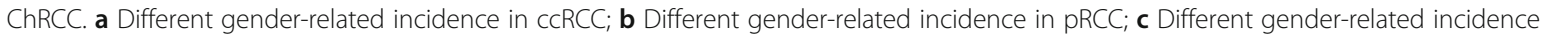
in ChRCC

partners. All TFE3 fusion partners have constitutively active gene promoters, so TFE3 fusion proteins are expressed at dramatically higher levels than wild-type TFE3. IHC technology is used commonly to diagnose Xp11.2 tRCC and TFE3 protein is the most distinctive immunohistochemical feature of Xp11 tRCC. This immunologic marker of Xp11.2 tRCC has a relatively high sensitivity and specificity $[17,32]$. However, TFE3 IHC can show false-positive results, TFE3 IHC combined with other diagnosis tools, such as break-part TFE3 fluorescence in situ hybridization (FISH), Reverse Transcription-Polymerase Chain Reaction (RT-PCR),

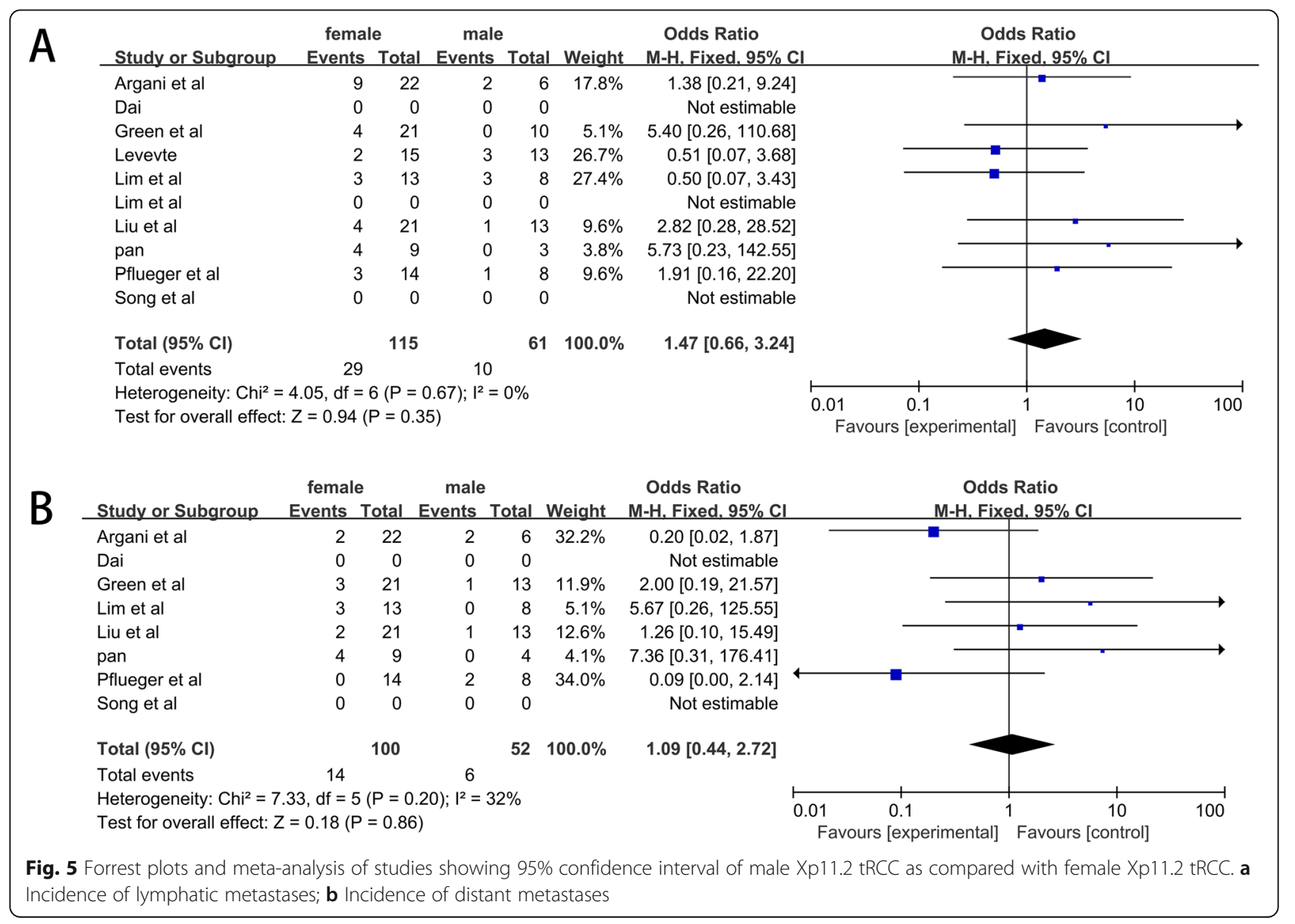


and cytogenetic analysis can be effective means to diagnose the Xp11.2 tRCC.

Xp11.2 tRCC showed significant differences between men and women compared with the common renal cell carcinoma. According to our results, the incidence of $\mathrm{Xp11.2} \mathrm{tRCC} \mathrm{is} \mathrm{much} \mathrm{higher} \mathrm{in} \mathrm{women} \mathrm{than} \mathrm{in} \mathrm{men}$ $(\mathrm{OR}=2.84,95 \% \mathrm{CI}=1.48-5.45)$. In adults, the rate rises even further $(\mathrm{OR}=3.37,95 \% \mathrm{CI}=2.19-5.18)$. Among the three most common types of kidney cancer, women had a lower incidence than men. We suggest that this significant difference may be due to the particular pathogenesis of Xp11.2 tRCC. In order to balance the difference of $\mathrm{X}$ chromosomes between male and female, female have two different $\mathrm{X}$ chromosomes, one of them is active (Xa) and the other one is inactive (Xi) while male only have one Xa chromosome. An lncRNA, the X-inactive specific transcript (Xist), is selectively expressed and physically coats one of the $\mathrm{X}$ chromosomes in the female, resulting in the one of $\mathrm{X}$ chromosomes inactivation $[18,19,33,34]$. The cause of Xp11.2 tRCC is the fusion of TFE3 on the short arm of the X chromosome. There are differences in the number of $\mathrm{X}$ chromosomes between men and women and X chromosome inactivation exists in women. We wonder if there was any effect on the different incidence between men and women. Whether this difference in incidence between men and women is related to the number of $\mathrm{X}$ chromosomes, and what role $\mathrm{Xa}$ and $\mathrm{Xi}$ play respectively, these questions are worthy of further study. The incidence of Xp11.2 tRCC varies between adults and children. Gender differences in child morbidity were not compared due to the small number of children in the included sample. However, in terms of the number of cases alone, the number of male and female cases in children appears to be equal. In other respects, there seems to be no significant difference between men and women in terms of lymphatic metastasis $(\mathrm{OR}=1.47,95 \% \mathrm{CI}=0.66-3.24)$ and distant metastasis $(\mathrm{OR}=1.09,95 \% \mathrm{CI}=0.44-1.72)$.

\section{Conclusions}

Therefore, compared to men, women have a higher incidence for patients with Xp11.2 tRCC. The outcome came out to the difference of $\mathrm{X}$ chromosomes between male and female. On the other hand, for the existence of three kinds $\mathrm{X}$ chromosomes, $\mathrm{Xa}$ of female, $\mathrm{Xi}$ of female, and $\mathrm{Xa}$ of male, the diversity of the $\mathrm{X}$ chromosome may lead to the different source of TFE3 fusion gene. Therefore, it could speculate that the distinction had something to do with the clinical stages, distant metastasis, and prognosis. Further work should be done to confirm this conjecture.

\section{Abbreviations}

RCC: Renal cell carcinoma; ccRCC: Clear cell renal cell carcinoma; pRCC: Papillary renal cell carcinoma; ChRCC: Chromophobe renal cell carcinoma; IHC: Immunohistochemistry; FISH: Fluorescence in situ hybridization; TFE3: Transcription factor binding to IGHM enhancer 3; RTPCR: Transcription-polymerase chain reaction

\section{Acknowledgements}

Not applicable.

\section{Authors' contributions}

NL, WZ contributed to study conception and design. WZ, NL contributed to data acquisition. WZ contributed to analysis and interpretation of data. WZ, $\mathrm{NL}$ contributed to drafting the manuscript. GH, WG, CZ were involved in revising the manuscript. All authors have read and approved the manuscript.

\section{Funding}

This work was supported by National Natural Science Foundation of China (ID: 81572512), Nanjing sci-tech developement project (ID:201803025).

\section{Availability of data and materials}

The data that support the findings of this study are available on request from the corresponding author Weidong Gan. The data are not publicly available due to them containing information that could compromise research participant privacy.

\section{Ethics approval and consent to participate}

All procedures performed in studies involving human participants were in accordance with the ethical standards of the institutional research committee and with the 1964 Helsinki declaration and its later amendments or comparable ethical standards. All procedures were approved by the Medical Ethics Committee for human Experiments of Nanjing Drum Tower Hospital, and our study did not violate any policies or procedures established by journal or described in "Specific Inappropriate Acts in Publication Process".

\section{Consent for publication}

Informed consent has been obtained from all individuals included in this study. We have acquired the written informed consent from patient for publication of this case report, images and all the information contained in

\section{Competing interests}

The authors declare that they have no competing interests.

Received: 3 June 2020 Accepted: 11 August 2020

Published online: 26 August 2020

\section{References}

1. Wu A, Kunju LP, Cheng L, Shah RB. Renal cell carcinoma in children and young adults: analysis of clinicopathological, immunohistochemical and molecular characteristics with an emphasis on the spectrum of Xp11.2 translocation-associated and unusual clear cell subtypes. Histopathology. 2008:53(5):533-44

2. Just PA, Letourneur F, Pouliquen C, Dome F, Audebourg A, Biquet P, Vidaud $M$, Terris $B$, Sibony M, Pasmant E. Identification by FFPE RNASeq of a new recurrent inversion leading to RBM10-TFE3 fusion in renal cell carcinoma with subtle TFE3 break-apart FISH pattern. Genes Chromosomes Cancer. 2016:55(6):541-8.

3. Argani P, Lui MY, Couturier JM, Bouvier R, Fournet J-C, Ladanyi M. A novel CLTC-TFE3 gene fusion in pediatric renal adenocarcinoma with $t\left(X_{i} 17\right)(p 11.2$; q23). Oncogene. 2003;22(34):5374.

4. Komai Y, Fujiwara M, Fujii Y, Mukai H, Yonese J, Kawakami S, Yamamoto S, Migita T, Ishikawa Y, Kurata M et al. Adult Xp11 Translocation Renal Cell Carcinoma Diagnosed by Cytogenetics and Immunohistochemistry. Clin Cancer Res. 2009;15(4):1170-6.

5. Magers MJ, Udager AM, Mehra R. MiT Family Translocation-Associated Renal Cell Carcinoma: A Contemporary Update With Emphasis on Morphologic, Immunophenotypic, and Molecular Mimics. Arch Pathol Lab Med. 139(10): 1224-33.

6. Lim B, You D, Jeong IG, Kwon T, Hong S, Song C, Cho YM, Hong B, Hong $\mathrm{J}$, Ahn $\mathrm{H}$. Clinicopathological features of Xp11.2 translocation renal cell carcinoma. Korean J Urol. 2015;56(3):212-7. 
7. Zhong M, Angelo PD, Osborne L, Paniz-Mondolfi AE, Cai D. Translocation renal cell carcinomas in adults. Am J Surg Pathol. 2012;36(5):654-62.

8. Zou H, Kang X, Pang $\sqcup$, Hu W, Zhao J, Qi Y, Hu J, Liu C, Li H, Liang W. Xp11 translocation renal cell carcinoma in adults: a clinicopathological and comparative genomic hybridization study. 2014;7(1):236-45.

9. Rao Q, Guan B, Zhou XJ. Xp11.2 translocation renal cell carcinomas have a poorer prognosis than non-Xp11.2 translocation carcinomas in children and young adults: a meta-analysis. Int J Surg Pathol. 2010;18(6):458-64.

10. Sirchia SM, Ramoscelli L, Grati FR, Barbera F, Coradini D, Rossella F, Porta G, Lesma E, Ruggeri A, Radice $P$ et al. Loss of the Inactive X Chromosome and Replication of the Active X in BRCA1-Defective and Wild-type Breast Cancer Cells. Cancer Res. 2005;65(6):2139-46.

11. Chaligné R, Heard E. X-chromosome inactivation in development and cancer. FEBS Lett. 2014;588(15):2514-22.

12. Kuthi L, Somorácz Á, Micsik T, Jenei A, Hajdu A, Sejben I, Imre D, Pósfai B, Kóczián K, Semjén D et al. Clinicopathological Findings on 28 Cases with XP11.2 Renal Cell Carcinoma. Pathology oncology research. POR 2020.

13. Dai C, Ruofan $S$, Yuqin D, Minglei $Y$, Jun $H$, Jianjun Z: Magnetic resonance imaging findings of renal cell carcinoma associated with Xp11.2 translocation/TFE3 gene fusion in adults: a pilot study. Abdominal radiology (New York). 2019;44(1):209-17.

14. Liu N, Wang Z, Gan W, Xiong L, Li D: Renal Cell Carcinoma Associated with Xp11.2 Translocation/TFE3 Gene Fusions: Clinical Features, Treatments and Prognosis. Plos One 2016, 11(11):e0166897.

15. Argani P, Olgac S, Tickoo SK, Goldfischer M, Moch H, Chan DY, Eble JN, Bonsib SM, Jimeno M, Lloreta J, et al. Xp11 Translocation Renal Cell Carcinoma in Adults: Expanded Clinical, Pathologic, and Genetic Spectrum. Am J Surg Pathol. 2007;31(8):1149-60.

16. Green WM, Yonescu R, Morsberger L, Morris K, Netto GJ, Epstein JI, Illei PB, Allaf M, Ladanyi M, Griffin CA. Utilization of a TFE3 break-apart FISH assay in a renal tumor consultation service. Am J Surg Pathol. 2013;37(8):1150-63.

17. Pflueger D, Sboner A, Storz M, Roth J, Moch H. Identification of molecular tumor markers in renal cell carcinomas with TFE3 protein expression by RNA sequencing. Neoplasia. 2013;15(11):1231-40.

18. Hong, Cheng, Song, Ning, Sun, Wei, Ping, Zhang, LeJian, He: Biological characteristics of pediatric renal cell carcinoma associated with Xp11.2 translocations/TFE3 gene fusions. Journal of Pediatric Surgery 2014.

19. Pan CC, Sung MT, Huang HY, Yeh KT. High chromosomal copy number alterations in Xp11 translocation renal cell carcinomas detected by Array comparative genomic hybridization are associated with aggressive behavior. Am J Surg Pathol. 2013;37(7):1116-9.

20. Beck SDW, Patel MI, Snyder ME, Kattan MW, Motzer RJ, Reuter VE, Russo P. Effect of papillary and chromophobe cell type on disease-free survival after nephrectomy for renal cell carcinoma. Ann Surg Oncol. 2004.

21. Teloken, PE, and, Thompson, R H, and, Satish, K: Prognostic Impact of Histological Subtype on Surgically Treated Localized Renal Cell Carcinoma. Journal of Urology 2009.

22. Keegan KA, Schupp CW, Chamie K, Hellenthal NJ, Evans CP, Koppie TM. Histopathology of surgically treated renal cell carcinoma: survival differences by subtype and stage. J Urol. 2012;188(2):391-7.

23. Steffens S, Janssen M, Roos FC, Becker F, Schumacher S, Seidel C, Wegener G, Thüroff JW, Hofmann R, Stöckle M. Incidence and long-term prognosis of papillary compared to clear cell renal cell carcinoma - a multicentre study. Eur J Cancer. 2012;48(15):2347-52.

24. Lee WK, Sang EL, Hong SK, Chang WJ, Byun SS. Characteristics and prognostic value of papillary histologic subtype in non-metastatic renal cell carcinoma in Korea: a multicenter study. Urol J. 2014;11(5):1884-90.

25. Costantini, M., Guaglianone, S., Simone, G., Ferriero, Papalia, Misuraca, R: Papillary type 2 versus clear cell renal cell carcinoma: Survival outcomes. European Journal of Surgical Oncology the Journal of the European Society of Surgical Oncology \& the British Association of Surgical Oncology 2016.

26. Wagener N, Edelmann D, Benner A, Zigeuner R, Brookman-May SD. Outcome of papillary versus clear cell renal cell carcinoma varies significantly in non-metastatic disease. PLoS One. 2017;12(9):e0184173.

27. Ellis $C L$, Eble JN, Subhawong AP, Martignoni G, Zhong M, Ladanyi M, Epstein Jl, Netto GJ, Argani P. Clinical heterogeneity of Xp11 translocation renal cell carcinoma: impact of fusion subtype, age, and stage. Mod Pathol. 2014;27(6):875-86

28. Sukov WR, Hodge JC, Lohse CM, Leibovich BC, Houston TR, Pearce KE, Wiktor AE, Cheville JC, Bedd P. TFE3 rearrangements in adult renal cell carcinoma: clinical and pathologic features with outcome in a large series of consecutively treated patients. Am J Surg Pathol. 2012;36(5):663.

29. Argani P, Aulmann S, Illei PB, Netto GJ, Weiss SW. A distinctive subset of PEComas harbors TFE3 gene fusions. Am J Surg Pathol. 2010;34(10):1395-406.

30. Next-Generation Sequencing of Translocation Renal Cell Carcinoma Reveals Novel RNA Splicing Partners and Frequent Mutations of ChromatinRemodeling Genes. Clin Cancer Res Official J Am Assoc Cancer Res. 2014; 20(15):4129-40.

31. Argani P, Zhong M, Reuter VE, Fallon JT, Epstein Jl, Netto GJ, AntonesCu CR. TFE3-fusion variant analysis defines specific Clinicopathologic associations among Xp11 translocation cancers. Am J Surg Pathol. 2016;40(6):723-37.

32. Argani $P$, Lal $P$, Hutchinson $B$, Man $Y L$, Ladanyi M. Aberrant nuclear Immunoreactivity for TFE3 in neoplasms with TFE3 gene fusions a sensitive and specific Immunohistochemical assay. Am J Surg Pathol. 2003;27(6):750-61.

33. Brown CJ, Ballabio A, Rupert JL, Lafreniere RG, Grompe M, Tonlorenzi R, Willard HF. A gene from the region of the human $X$ inactivation Centre is expressed exclusively from the inactive X chromosome. Nature. 1991; 349(6304):38-44.

34. Panning B, Jaenisch R. DNA hypomethylation can activate Xist expression and silence X-linked genes. Genes Dev. 1996;10(16):1991-2002.

\section{Publisher's Note}

Springer Nature remains neutral with regard to jurisdictional claims in published maps and institutional affiliations.
Ready to submit your research? Choose BMC and benefit from:

- fast, convenient online submission

- thorough peer review by experienced researchers in your field

- rapid publication on acceptance

- support for research data, including large and complex data types

- gold Open Access which fosters wider collaboration and increased citations

- maximum visibility for your research: over $100 \mathrm{M}$ website views per year

At BMC, research is always in progress.

Learn more biomedcentral.com/submissions 